Article

\title{
Calculation of the Electronic Parameters of an Al/DNA/p-Si Schottky Barrier Diode Influenced by Alpha Radiation
}

\author{
Hassan Maktuff Jaber Al-Ta'ii ${ }^{1,2, *}$, Yusoff Mohd Amin ${ }^{1}$ and Vengadesh Periasamy ${ }^{1, *}$ \\ 1 Department of Physics, Faculty of Science, University of Malaya, 50603 Kuala Lumpur, Malaysia \\ 2 Department of Physics, Faculty of Science, University of Al-Muthanna, Samawah 66001, Iraq \\ * Authors to whom correspondence should be addressed; \\ E-Mails: hassankirkukly@gmail.com (H.M.J.A.-T.); vengadeshp@um.edu.my (V.P.); \\ Tel.: +60-162-639-762 (V.P.).
}

Academic Editor: Matteo Castronovo

Received: 4 December 2014 / Accepted: 14 January 2015 / Published: 26 February 2015

\begin{abstract}
Many types of materials such as inorganic semiconductors have been employed as detectors for nuclear radiation, the importance of which has increased significantly due to recent nuclear catastrophes. Despite the many advantages of this type of materials, the ability to measure direct cellular or biological responses to radiation might improve detector sensitivity. In this context, semiconducting organic materials such as deoxyribonucleic acid or DNA have been studied in recent years. This was established by studying the varying electronic properties of DNA-metal or semiconductor junctions when exposed to radiation. In this work, we investigated the electronics of aluminium (Al)/DNA/silicon ( $\mathrm{Si}$ ) rectifying junctions using their current-voltage (I-V) characteristics when exposed to alpha radiation. Diode parameters such as ideality factor, barrier height and series resistance were determined for different irradiation times. The observed results show significant changes with exposure time or total dosage received. An increased deviation from ideal diode conditions (7.2 to 18.0) was observed when they were bombarded with alpha particles for up to $40 \mathrm{~min}$. Using the conventional technique, barrier height values were observed to generally increase after 2, 6, 10, 20 and 30 min of radiation. The same trend was seen in the values of the series resistance $(0.5889-1.423 \Omega$ for $2-8 \mathrm{~min})$. These changes in the electronic properties of the DNA/Si junctions could therefore be utilized in the construction of sensitive alpha particle detectors.
\end{abstract}


Keywords: alpha particles; Norde's method; series resistance; height barrier; ideality factor; hypersensitivity

\section{Introduction}

One of the most commonly used rectifying connections in the electronics industry are metal-semiconductor (MS) contact or Schottky barrier diodes (SBDs), employed in a huge number of devices including solar cells, microwave diodes, field-effect photodetectors and transistors (FETs) [1]. These devices have often been used in telecommunication systems, radio astronomy, radar technology, and plasma diagnostics [2]. In recent decades due to the limitations of conventional materials, organic semiconductors such as deoxyribonucleic acid (DNA) and others have found many uses in electrical and optoelectronic applications. DNA can be used in the design and production of novel hybrid semiconductor devices such as photovoltaic devices and diodes [3,4]. Other materials such as conductive polymers and organic compounds have also been shown to achieve rectifying junctions like metal and inorganic semiconductors [5].

DNA in particular is a polymorphic molecule which structures are strongly affected by the environment [6,7]. Due to the potential exciting applications of DNA electronics [8], intensified research has been undertaken in the fields of biophysics, chemistry and biomedical research over the past few decades. Khatir et al. studied the effect of the magnetic field on Au/DNA/Au diodes. The authors observed a decrease in the barrier height values and increase in the resistance upon an increase in the magnetic field, suggesting potential application as magnetic sensors [9].

Güllü et al. studied the changes in electronic properties of Al/DNA/Si sandwich type junctions for current-voltage (I-V) characterization with temperature $(200-300 \mathrm{~K})$. They determined the effect of temperature on ideality factors, $n ; 1.34 \pm 0.02$ and $1.70 \pm 0.02$ at $300 \mathrm{~K}$ and $200 \mathrm{~K}$, respectively. The barrier heights $(\phi b)$ were calculated as $(0.75 \pm 0.01) \mathrm{eV}$ at $300 \mathrm{~K}$, decreasing to $(0.61 \pm 0.01) \mathrm{eV}$ at $200 \mathrm{~K}$. These values demonstrated the suitability of the Al/DNA/p-type silicon (p-Si) Schottky diode as a good alternative to standard temperature sensors. Meanwhile Okur et al. [10] discussed the electrical characterization of $\mathrm{Au} / \mathrm{DNA} / \mathrm{n}-\mathrm{Si}$ Schottky diodes by employing the I-V curve and interface state density measurements. Kim et al. [11] observed that the conductivity of DNA molecules increased with heat. This was regardless of whether the heating was carried out under ambient or non-ambient conditions, while using $\mathrm{N}_{2}$ and $\mathrm{O}_{2}$ as the dopant at low temperatures. Furthermore, Gupta et al. [12] in their work illustrated that the p-Si/DNA junction can be used as an optical sensor. They measured the photoresponse properties of the diodes, which consist of the ideality factor $(1.2 \pm 0.1)$ and barrier height $(0.56 \pm 0.02 \mathrm{eV})$. At low radiation frequencies, the capacitance of the diodes increased as a result of the change in the interfacial states. Many researchers in the field of chemistry have studied luminophores and demonstrated a huge difference in oligonucleotide schemes, which have been used to manufacture luminescent DNA-based probes [13].

In our present study of the effect of alpha $(\alpha)$ radiation on DNA, we used a mushroom-based DNA layer on a $\mathrm{p}-\mathrm{Si}$ wafer to fabricate $\mathrm{Al} / \mathrm{p}-\mathrm{Si} / \mathrm{DNA} / \mathrm{Al}$ diode structures. To the best of our knowledge, no studies on the effects of alpha radiation on similar structures have ever been reported before. The aim 
of this study is therefore to fabricate a DNA-based MS diode for potential utilization as an alpha particle detector/sensor. I-V measurements were then performed to analyze the electrical properties of the DNA-based MS diode as the radiation sensitive material.

\section{Materials and Methods}

\subsection{Preparation of DNA Solution}

A simple preparation procedure of mushroom DNA extracted from fruiting bodies was used for Polymerase Chain Reaction (PCR) amplification. The procedure starts with the collection of minute quantities of mycelium (0.1-1.0 g) from the fruiting body (stipe) of an Oyster mushroom species (Pleurotus spp) using sterilized tweezers. Standard procedures [14] were further employed to yield pure DNA samples prior to the PCR process. The DNA of all samples was amplified by PCR (PTC-100TM, MJ Research Inc., Ramsey, MN, USA) using the universal primers ITS1 forward (5'-TCC GTA GGTGA AC CTGCGG-3') and ITS4 reverse (5'-TCCTCCGCTT ATT GATATGC-3'). Amplification reactions were performed in a total volume of $50.0 \mu \mathrm{L}$ containing $10 \times$ PCR buffer $4.0 \mu \mathrm{L}$, dNTP mix $2.5 \mu \mathrm{L}, 2.5 \mu \mathrm{L}$ of each primer, $1.0 \mu \mathrm{L}$ of Taq polymerase (Cosmo, Seongnam-si, Gyeonggi-do, Korea), $4.0 \mu \mathrm{L}$ of DNA genomic (Template), and $26.0 \mu \mathrm{L}$ of sterilized distilled water. PCR amplification as carried-out in 30 cycles at $94{ }^{\circ} \mathrm{C}$ for $30 \mathrm{~min}$ and denatured at $50{ }^{\circ} \mathrm{C}$ for $60 \mathrm{~min}$ followed by annealing at $72{ }^{\circ} \mathrm{C}$ for an extension of $1 \mathrm{~min}$. Initial denaturing at $95{ }^{\circ} \mathrm{C}$ was extended to $5 \mathrm{~min}$ and the final extension was at $72{ }^{\circ} \mathrm{C}$ for $5 \min [15,16]$.

\subsection{Preparation of Al/DNA/p-Si/Al Junctions}

Junctions were been prepared using a polished p-type Si wafer with [100] orientation with thickness and resistivity of $(650 \pm 25) \mu \mathrm{m}$ and (1-10) $\Omega-\mathrm{cm}$, respectively (Polishing Corporation of America, Santa Clara, CA, USA). The wafer was chemically cleaned using the RCA cleaning procedure; i.e., 10 min boil in $\mathrm{NH}_{4}+6 \mathrm{H}_{2} \mathrm{O}+\mathrm{H}_{2} \mathrm{O}_{2}$ followed by a 10 min boil in $\mathrm{HCl}+\mathrm{H}_{2} \mathrm{O}_{2}+6 \mathrm{H}_{2} \mathrm{O}$ solution. Then, a low-resistivity ohmic back contact to the p-type $\mathrm{Si}$ wafer was made by using Al, followed by heat treatment at $570{ }^{\circ} \mathrm{C}$ for $3 \mathrm{~min}$ in $\mathrm{N}_{2}$ atmosphere. The native oxide on the front surface of the Si wafer was removed by immersing in $\mathrm{HF}+\mathrm{H}_{2} \mathrm{O}$ (1:10) solution before rinsing in deionized water (18.2 M $\Omega-\mathrm{cm}$, Barnstead Nanopure II water system, Lake Balboa, CA, USA) for $30 \mathrm{~s}$. Other necessary chemicals ( $\mathrm{NH}_{3}, \mathrm{H}_{2} \mathrm{O}_{2}, \mathrm{HF}, \mathrm{HCl}$ and acetone) were supplied by Sigma Aldrich (St. Louis, MO, USA) and were used without further purification. After which, formation of the organic DNA layer was carried-out by using a micro syringe (Hamilton) containing $10.0 \mu \mathrm{L}$ DNA with concentration of $1.80 \mathrm{ng} / \mu \mathrm{L}$ from the pre-prepared DNA solution. Schottky metal contacts were then deposited on the organic layer using a metal shadow mask by evaporating Al metal wire (Kurt J. Lesker, Hudson Valley, PA, USA) of $99.999 \%$ purity. The Al contacts had dimensions of $2.0 \mathrm{~mm}, 2000 \AA$ and $3.14 \times 10^{-2} \mathrm{~cm}^{2}$ of diameter, thickness and area, respectively. All evaporation processes were carried-out in a vacuum thermal metal evaporator coating unit (Edward Auto 306, West Sussex, UK) pressurized to about $10^{-7}$ mbar. The prepared DNA based devices were air-dried for $24 \mathrm{~h}$ in a class 1000 clean room before carrying out the irradiation by alpha particles. Sample irradiation by alpha particles was achieved using ${ }^{241} \mathrm{Am}$ with an activity of $150 \mathrm{nCurie}$ and $\mathrm{t}_{1 / 2}$ of 457 years for periods of 
2, 4, 6, 8, 10, 20, 30 and $40 \mathrm{~min}$. It's corresponding I-V profiles were finally recorded in dark using an electrometer (SMU-236, Keithley, OH, USA) at room temperature. Figure 1 depicts the schematic diagram of the DNA based sensors fabricated in this work.

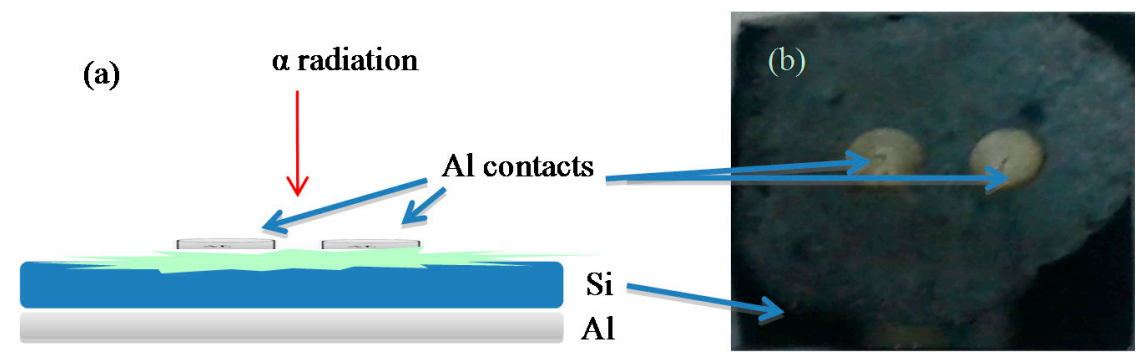

Figure 1. (a) Cross section view of Al/DNA/Si surface-type Schottky diodes made on the same substrate and (b) the actual images of the sensors.

\section{Results and Discussion}

The forward and reverse bias $\mathrm{I}-\mathrm{V}$ characteristics of the $\mathrm{Al} / \mathrm{DNA} / \mathrm{p}-\mathrm{Si} / \mathrm{Al}$ junctions at room temperature are given in Figure 2. As can be observed, the I-V characteristics of the device demonstrate a rectifying behavior.

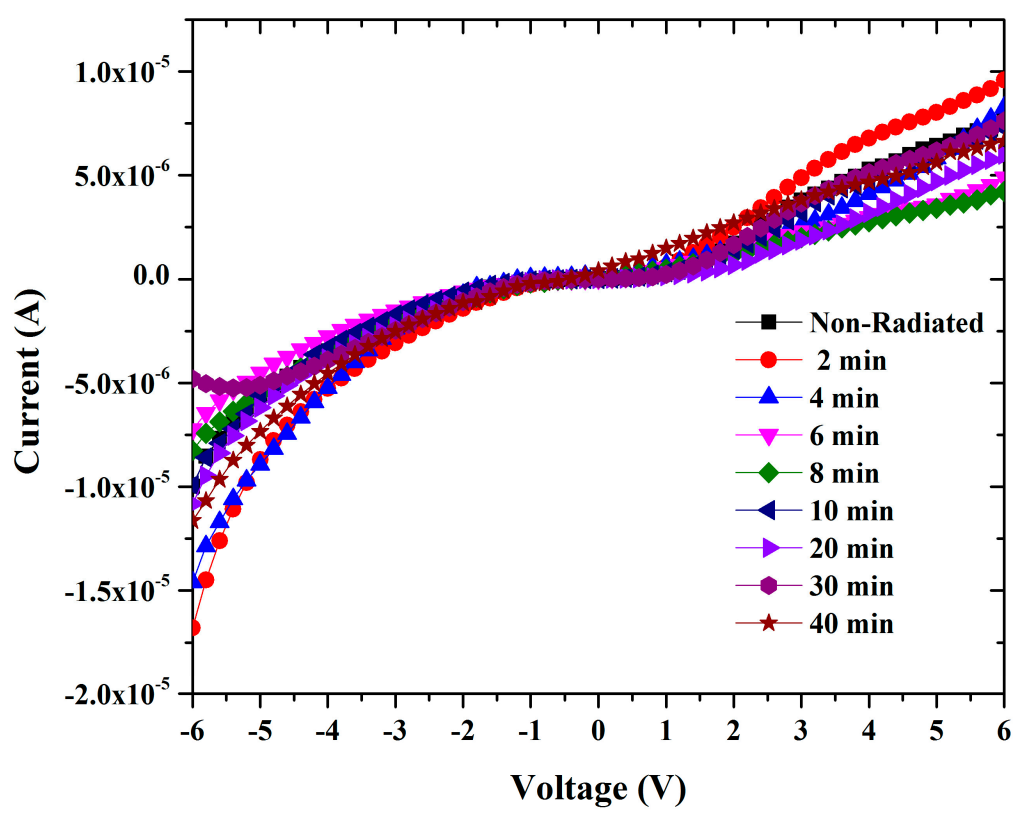

Figure 2. Graphs demonstrates the relationship between current and voltage for forward and reverse biases.

According to the thermionic emission theory, the I-V characteristics of a diode is given by [17];

$$
\begin{gathered}
I=I_{0} \exp \left(\frac{q V}{n K T}\right)\left[1-\exp \left(\frac{-q V}{K T}\right)\right] \\
I_{0}=A^{*} T^{2}\left(\frac{-q \Phi}{K T}\right)
\end{gathered}
$$


where $\mathrm{q}$ represents the electron charge, the applied voltage by $\mathrm{V}$ and effective Richardson constant by symbol $\mathrm{A}^{*}$ and equal to $32 \mathrm{~A} / \mathrm{cm}^{2} \mathrm{~K}^{2}$ for p-type Si [18]. Symbol A meanwhile represents the active diode area, $\mathrm{T}$ the absolute temperature, $\mathrm{K}$ the Boltzmann constant, $\mathrm{n}$ the ideality factor of a SBD and $\Phi_{b o}$ the zero bias barrier height. For values of $\mathrm{V}>3 \mathrm{kT} / \mathrm{q}$, the ideality factor from Equation (1) can be re-written as:

$$
\mathrm{n}=\frac{\mathrm{q}}{\mathrm{KT}}\left(\frac{\mathrm{dV}}{\mathrm{d} \ln \mathrm{I}}\right)
$$

The ideality factor determined from the slope of the linear region of the forward bias $(\ln (\mathrm{I})-\mathrm{V})$ characteristic through the relation in Equation (3) is a measure of conformity of diode to pure thermionic emission [19,20]. Figure 3 shows ideality factor fluctuations of Al/DNA/pi-Si/Al based junctions fabricated in this work calculated using Equation (3).

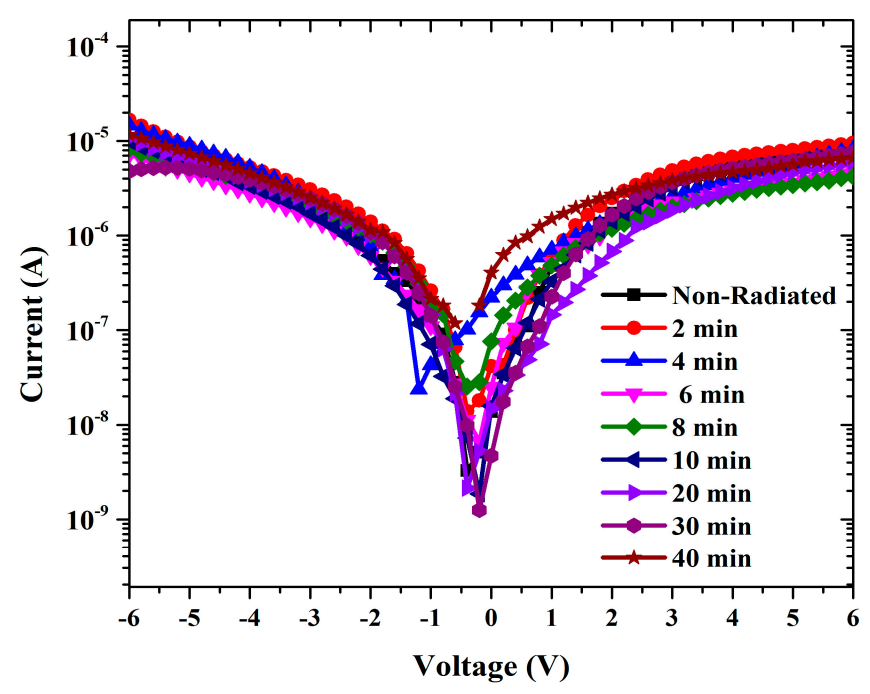

Figure 3. Curves show the $\mathrm{I}-\mathrm{V}$ characteristics of $\mathrm{Al} / \mathrm{DNA} / \mathrm{p}-\mathrm{Si}$ Schottky diode at room temperature.

For both the radiated and non-radiated samples, the linear region of the forward bias I-V plots indicates that the effect of the series resistance in this region is not important. The value of the barrier height $(\Phi)$ of the Al/DNA/p-Si/Al Schottky diode was $0.7468 \mathrm{eV}$ before irradiation. The values before and after irradiation (Table 1) were calculated from the y-axis intercepts of the semi log-forward bias $\mathrm{I}-\mathrm{V}$ plots using Equation (4). It ought to be noted that $\Phi$ is the connection potential barrier that exists at the interface between inorganic and organic layers, i.e., at the DNA/p-Si interface:

$$
\Phi=\frac{\mathrm{KT}}{\mathrm{q}} \ln \left(\frac{\mathrm{AA}^{*} \mathrm{~T}^{2}}{\mathrm{I}_{\mathrm{o}}}\right)
$$

The values of series resistance are calculated from the junction resistance formula $\mathrm{R}_{\mathrm{S}}=\partial V / \partial I$ from the I-V properties of the diode. The resistance Rs versus voltage of the surface-type Schottky diode is demonstrated in Figure 4. From the figure, it can be concluded that at low voltages $(\leq 2.0 \mathrm{~V})$, Rs values were the highest for 20,30 and $10 \mathrm{~min}$ in reducing order, followed by the non-radiated sample. However above $2.0 \mathrm{~V}$, the Rs values become insignificant. 
Table 1. Values of ideality factor, barrier height and series resistance measured.

\begin{tabular}{|c|c|c|c|c|c|c|c|c|c|c|}
\hline \multirow{2}{*}{$\begin{array}{c}\text { Radiation } \\
\text { Time } \\
\text { (Minutes) }\end{array}$} & \multicolumn{3}{|c|}{ Conventional Method } & \multicolumn{4}{|c|}{ Cheung and Cheung Method } & \multicolumn{3}{|c|}{ Norde Method } \\
\hline & $\mathbf{n}$ & $\begin{array}{c}\Phi(e V) \\
(\ln (\mathrm{I})-\mathrm{V})\end{array}$ & $\mathbf{R}_{\mathrm{S}}(\mathbf{M} \Omega)$ & $\begin{array}{c}\Phi(\mathrm{eV}) \\
\mathrm{H}(\mathrm{I}) \\
\end{array}$ & $\begin{array}{c}\text { Rs }_{\text {(MS) }} \\
\mathbf{H}(\mathrm{I})\end{array}$ & n dV/lnI & $\begin{array}{c}R_{S}(M \Omega) \\
d V / I n I\end{array}$ & $\begin{array}{c}\mathbf{F}(\mathbf{V}) \\
(\mathbf{V})\end{array}$ & $\begin{array}{c}\Phi(e V) \\
(F-V) \\
\end{array}$ & $\begin{array}{c}\mathrm{Rs}_{\mathrm{s}}(\mathrm{M} \Omega) \\
(\mathrm{F}-\mathrm{V}) \\
\end{array}$ \\
\hline 0 & 8.2643 & 0.7486 & 0.7772 & 0.6050 & 0.81 & 0.6202 & 0.066 & 0.7541 & 0.7482 & 0.7342 \\
\hline 2 & 9.0139 & 0.7553 & 0.5889 & 0.6213 & 0.56 & 0.2481 & 0.046 & 0.7471 & 0.7612 & 0.2567 \\
\hline 4 & 7.2683 & 0.6876 & 0.7263 & 0.6742 & 0.66 & 1.1628 & 0.053 & 0.699 & 0.6931 & 0.0861 \\
\hline 6 & 8.5814 & 0.7429 & 1.2280 & 0.6409 & 1.20 & 0.2984 & 0.093 & 0.7353 & 0.7294 & 0.3544 \\
\hline 8 & 12.2826 & 0.7127 & 1.4230 & 0.6758 & 1.10 & 1.4341 & 0.086 & 0.7180 & 0.7121 & 0.1804 \\
\hline 10 & 10.1212 & 0.7582 & 0.7985 & 0.6225 & 0.84 & 0.3178 & 0.067 & 0.7550 & 0.7491 & 0.7601 \\
\hline 20 & 10.9747 & 0.7594 & 0.9995 & 0.6834 & 0.92 & 1.3566 & 0.071 & 0.7650 & 0.7591 & 1.1257 \\
\hline 30 & 7.6935 & 0.7872 & 0.7872 & 0.9878 & 0.90 & 0.8915 & 0.073 & 0.7720 & 0.7661 & 1.4733 \\
\hline 40 & 18.2579 & 0.6720 & 0.3217 & 0.6025 & 0.76 & 0.2636 & 0.060 & 0.6803 & 0.6744 & 0.0416 \\
\hline
\end{tabular}

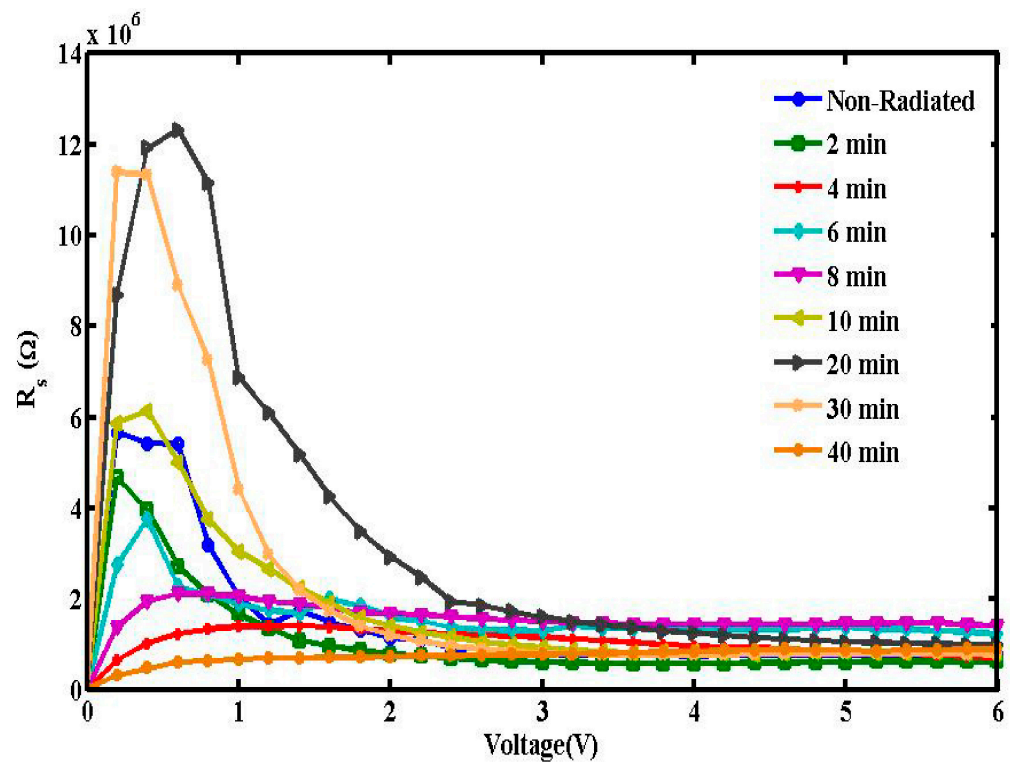

Figure 4. Relation between series resistance and voltage measured using the conventional method.

At high currents, there is always a deviation of the ideality that has been obviously shown to rely on bulk series resistance and the interfacial state density, as one would expect. The lower the series resistance and the interface state density, the better is the range over which $\ln I(\mathrm{~V})$ does in reality yield a straight line. The Schottky diode factors such as the barrier height $\Phi_{\mathrm{bo}}$, the series resistance Rs and the ideality factor $n$ were also determined using the technique advanced by Cheung and Cheung [21]. The method's functions can be written as:

$$
\begin{gathered}
\frac{\mathrm{dV}}{\mathrm{d}(\ln \mathrm{I})}=\mathrm{IR}_{\mathrm{S}}+\mathrm{n} \frac{\mathrm{KT}}{\mathrm{q}} \\
\mathrm{H}(\mathrm{I})=\mathrm{V}-\left(\frac{\mathrm{KT}}{\mathrm{q}}\right) \ln \left(\frac{\mathrm{I}}{\mathrm{AA}^{*} \mathrm{~T}^{2}}\right)
\end{gathered}
$$

therefore:

$$
\mathrm{H}(\mathrm{I})=\mathrm{IR}_{\mathrm{S}}+\mathrm{n} \Phi_{\mathrm{b}}
$$


Figure 5a,b shows the experimental $\mathrm{H}(\mathrm{I})$ versus $\mathrm{I}$ and $\mathrm{dV} / \mathrm{d}(\mathrm{ln} \mathrm{I})$ versus $\mathrm{I}$ plots for the $\mathrm{Al} / \mathrm{DNA} / \mathrm{Si}$ Schottky diode at room temperature. A plot of H(I) versus I (Figure 5a) shows a straight line with intercept at $y$-axis equal to $\mathrm{n} \Phi$. $\Phi$ was obtained by substituting the $\mathrm{n}$ value from Equation (5) and the data of the downward curvature region in the forward bias I-V graph from Equation (7). The slope of this plot also limits Rs, which can be utilized to check the accuracy of Cheung and Cheung's method. From H(I) versus I, the $\Phi$ and Rs values were measured and presented in Table 1. Equation (5) gives a straight line for the data of the downward curvature region in the forward bias I-V graph.
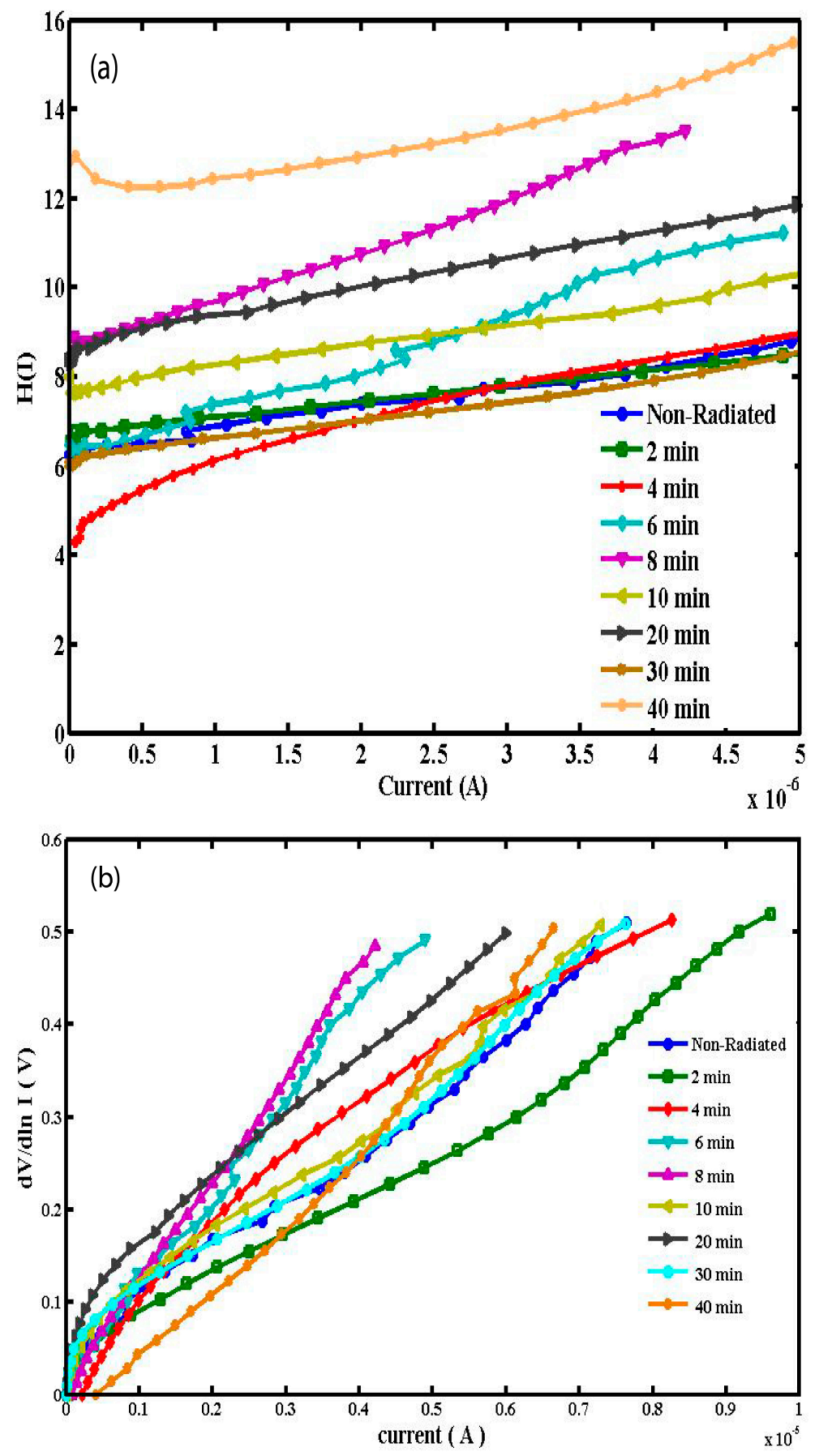

Figure 5. $\mathrm{H}(\mathrm{I})$ and $\mathrm{dV} / \mathrm{d}(\ln \mathrm{I})$ versus $\mathrm{I}$ graphs obtained from forward bias $\mathrm{I}-\mathrm{V}$ characteristics of Al/DNA/Si/Al Schottky junction diode. 
Figure 5 b shows the plot of $d V / d(\ln I)$ versus $\mathrm{I}$, from which the values of $\mathrm{n}$ and Rs were calculated (Table 1). As can be seen in the table, the values of Rs obtained from $\mathrm{dV} / \mathrm{d}(\mathrm{ln} \mathrm{I})$ versus $\mathrm{I}$ and $\mathrm{H}(\mathrm{I})$ versus I plots are in near agreement with each other. Radiation dose however does play an important role in changing the resistance values, thus the resistance increases gradually at low doses, which therefore enables the DNA to seek self-protection. Plots of $\Phi, \mathrm{n}$ and Rs with radiation periods as shown in Figures 6 and 7 therefore indicate the hypersensitivity phenomena of the DNA at low dose.

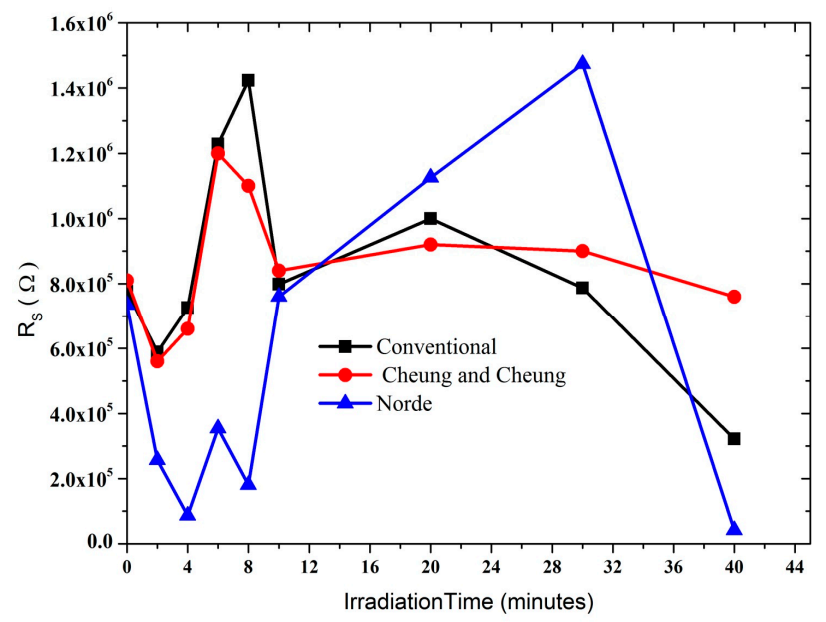

Figure 6. Graphs explaining the relationship between series resistance and alpha radiation time.
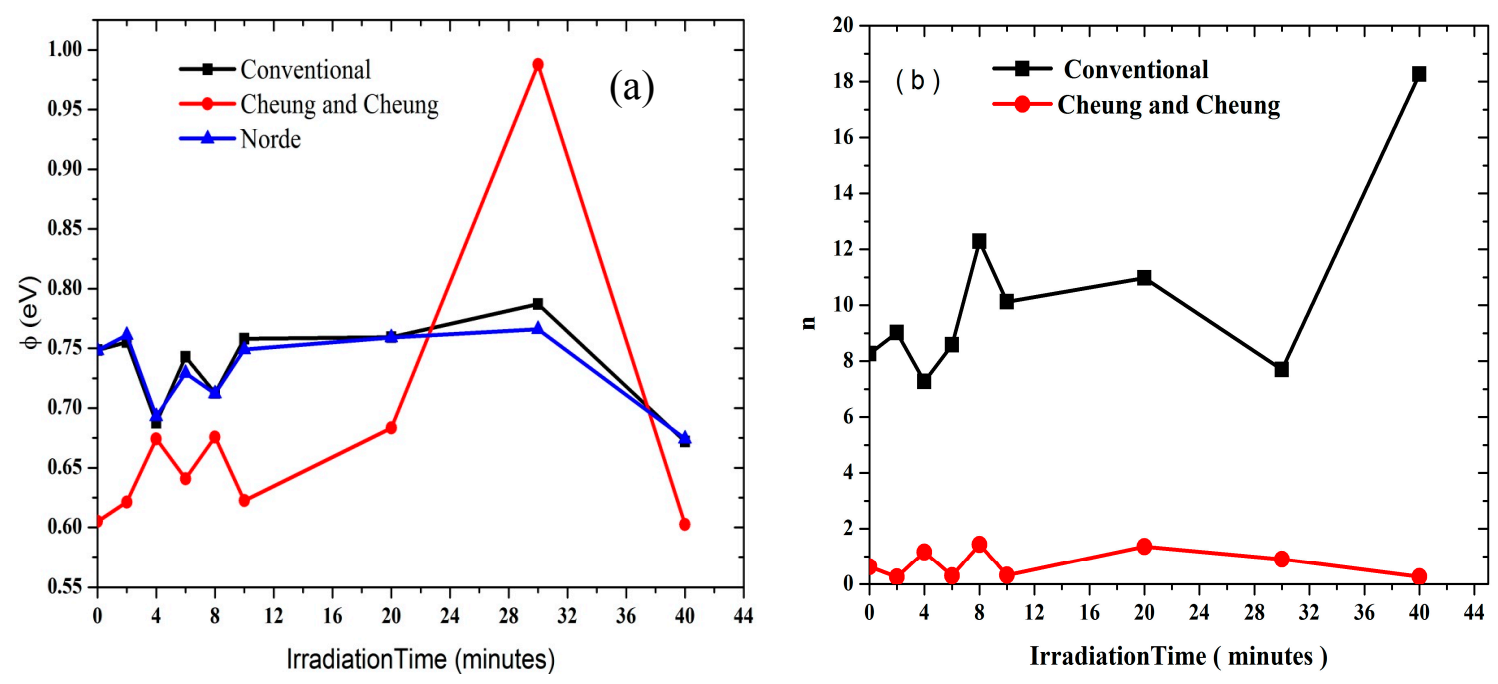

Figure 7. Graphs demonstrating the relationship between ideality factor and barrier height with the radiation time.

$\Phi_{\mathrm{b}}$ is the real barrier height derived from the low-voltage part of the forward I-V characteristics. The series resistance was obtained from the straight-line region seen in Figure 5. Using Equation (7), the values of barrier height and the series resistance were then obtained and the results presented in Table 1. The table lists values of $n, \Phi_{b}$, Rs obtained from both the conventional and the Cheung and Cheung models. Generally, values of $n$ obtained from the $\mathrm{dV} / \mathrm{d}(\ln \mathrm{I})$ versus I curve is lower than that of the forward bias $\ln I$ versus $V$ plot. This can be attributed to the effect of the series resistance, interface states and voltage drop across interfacial layers [22-24] and radiation effect [25]. 
Norde's method is an alternative method to calculate the series resistance and barrier height [26,27]. The following function has been derived in the modified Norde method:

$$
\mathrm{F}(\mathrm{V})=\frac{\mathrm{V}}{\gamma}-\frac{\mathrm{KT}}{\mathrm{q}} \ln \left(\frac{\mathrm{I}}{\mathrm{AA}^{*} \mathrm{~T}^{2}}\right)
$$

and effective Schottky barrier height is given by:

$$
\Phi=\mathrm{F}\left(\mathrm{V}_{\min }\right)+\frac{\mathrm{V}_{\min }}{\gamma}-\frac{\mathrm{KT}}{\mathrm{q}}
$$

and:

$$
\mathrm{R}_{\mathrm{S}}=\frac{\mathrm{KT}}{\mathrm{qI}_{\mathrm{o}}}
$$

where $\mathrm{F}\left(\mathrm{V}_{\min }\right)$ is the minimum point in the $\mathrm{F}(\mathrm{V})$ versus $\mathrm{V}$ curve, $\mathrm{V}_{\min }$ and $\mathrm{I}_{\mathrm{o}}$ are the corresponding voltage and current respectively.

A plot of $\mathrm{F}(\mathrm{V})$ versus $\mathrm{V}$ at room temperature is shown in Figure 8. The values of $\Phi$ and $\mathrm{R}_{\mathrm{s}}$ from the plot $\mathrm{F}(\mathrm{V})$ versus $\mathrm{V}$ are listed in Table 1. Norde's method demonstrates that the values of Rs diverge close to non-radiation values when calculated using the conventional method. At lower radiation doses, a significant decrease in series resistance was observed. However, an increase is seen within 10 to $30 \mathrm{~min}$ of radiation, registering a drop again at $40 \mathrm{~min}$. The increase may be attributed to the decrease in free carrier concentration and charge mobility. Higher barrier height values denote lower reverse currents [28]. Furthermore, the hypersensitivity phenomenon was responsible for the increase in the $\Phi$ and Rs values.

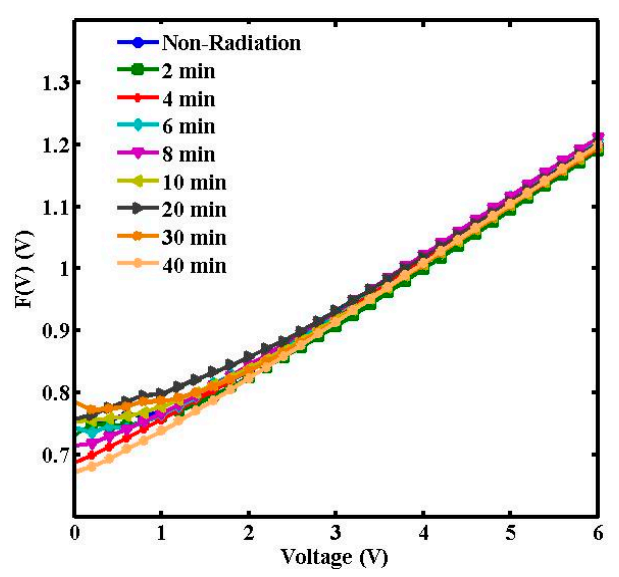

Figure 8. F(V) vs. V plots of the radiated and non-radiated Al/DNA/Si Schottky diodes.

In all the methods, values of the barrier heights were observed to converge. The series resistance initially decreased and later increased with increasing radiation time (Figure 6) as the result of the increasing number of alpha particle tracks. At lower dosages, the ideality factor dropped dramatically demonstrating the hypersensitivity phenomena of the DNA molecules (Figure 7b), which may act to protect against harmful alpha radiation. This phenomenon seems to be similar to the relationship observed between survival curves and radiation dosage [27,29,30]. Schottky barrier height on the other hand has an inverse proportionality relationship with the ideality factor as seen in Figure $7 \mathrm{a}$. 
Radiation effect on DNA thin films were also studied using Raman spectroscopic analysis (Renishaw, inVia Raman Microscope, Gloucestershire, UK, 325 and $514 \mathrm{~nm}$ lasers) to determine the influence of exposure time. DNA without radiation exposure shows Raman bands of adenine, cytosine, guanine and thymine bases and phosphate backbone groups with different modes of DNA. The Raman bands observed are $1244 \mathrm{~cm}^{-1}$ bending of C-H and stretching of C-N bonds; $1418 \mathrm{~cm}^{-1}$ stretching bond of adenine; $1290 \mathrm{~cm}^{-1} \mathrm{C}-\mathrm{C}$ bond stretching; $1345 \mathrm{~cm}^{-1}$ stretching of $\mathrm{C}-\mathrm{N}$ and $\mathrm{C}=\mathrm{C}$ in cytosine; $1576 \mathrm{~cm}^{-1}$ $\mathrm{C}-\mathrm{N}-\mathrm{C}=\mathrm{C}$ stretching bonds in guanine; $1290 \mathrm{~cm}^{-1} \mathrm{C}-\mathrm{C}$ bond stretching; $1465 \mathrm{~cm}^{-1}$ stretching of C-N bonds in thymine; $1068 \mathrm{~cm}^{-1}$ symmetric stretching and $1146 \mathrm{~cm}^{-1}$ stretching mode of the phosphate backbone.

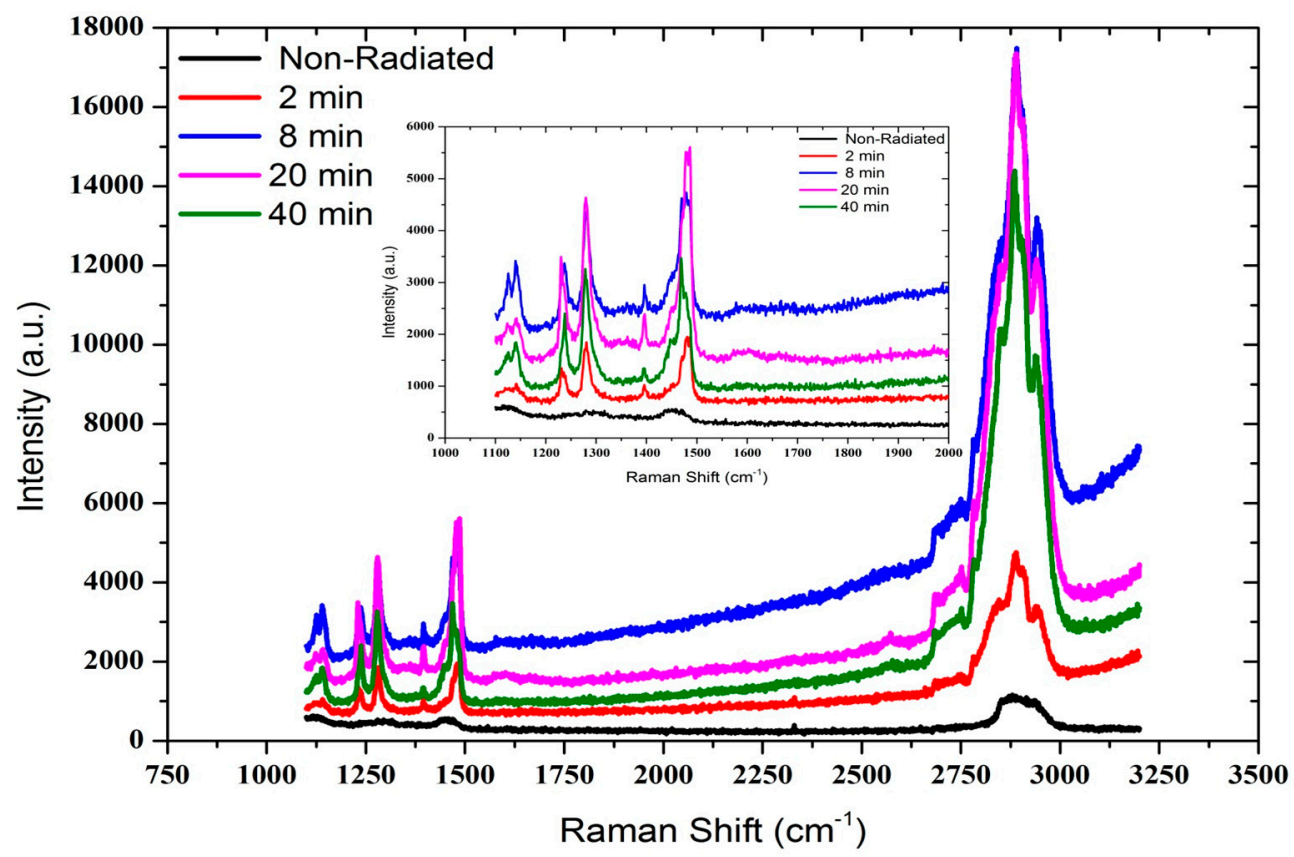

Figure 9. Raman spectra of $\mathrm{Al} / \mathrm{DNA} / \mathrm{p}-\mathrm{Si} / \mathrm{Al}$ junctions with and without alpha exposure. The insert figure shows the larger view of the peaks to the left of the spectrum.

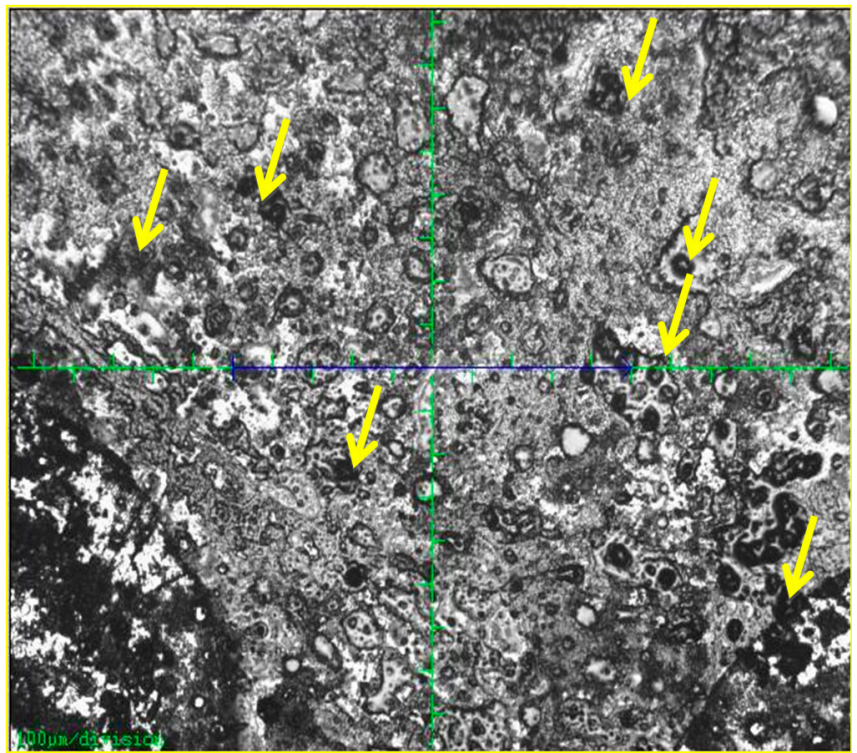

Figure 10. Alpha particle tracks as indicated by the yellow arrows can be clearly observed on the DNA film samples. 
Our results are similar with those reported by Kulkarni et al. [31]. In the irradiated sample, clear shifting of these peaks can be observed due to the alpha exposures (Figure 9). This is caused by structural damage as a result of absorption of the radiation energy. The peak intensities gradually increased with increasing exposure time (and therefore the dosage) to the ${ }^{241} \mathrm{Am}$ radiation source. Increase in the alpha particle irradiation time leads to the linear increase of the number of tracks (Figure 10) and the significant intensity changes observed in the Raman spectrum (Figure 9).

\section{Conclusions}

In this study, we fabricated sandwich type Al/DNA/p-Si Schottky barrier diodes and generated I-V measurements upon exposure to increasing dosage of alpha radiation at room temperature. The values of the series resistances, ideality factors and barrier heights were calculated from the measured non-ideal I-V curve, conventional, Norde and Cheung and Cheung techniques were estimated for the devices. From the conventional method, the calculated $\Phi$ value for non-radiated was $0.749 \mathrm{eV}$, which increased to $0.755 \mathrm{eV}$ after $4 \mathrm{~min}$ of radiation. Furthermore barrier height values were observed to increase after 6,10, 20 and $30 \mathrm{~min}$ of radiation, except for 4 and $40 \mathrm{~min}$, which registered a decrease of about $0.68 \mathrm{eV}$. The electrical resistance increase may be due to drop in the forward current at high voltages whereas the drop in barrier height values is as a result of the growth of the reverse current [28]. Hypersensitivity of DNA to radiation is thought to be responsible for changes in the ideality factors and series resistance. The various parameters studied therefore demonstrate the potential application of the fabricated $\mathrm{Al} / \mathrm{DNA} / \mathrm{p}-\mathrm{Si}$ junction type sensor for detecting alpha particles.

\section{Acknowledgments}

Financial assistance provided by the FRGS (FP004-2013A) and HIR (J-21002-73823) grants are greatly appreciated. The first author would also like to thank the Ministry of Higher Education and Scientific Research of Iraq for the financial assistance provided for his PhD study.

\section{Author Contributions}

H.M.J.A.-T and V.P. conceived and designed the experiments; H.M.J.A.-T performed the experiments; H.M.J.A.-T and V.P. analyzed the data; V.P. and Y.M.A contributed reagents/ materials/analysis tools; H.M.J.A.-T and V.P. wrote the paper.

\section{Supplementary Information}

Supplementary materials can be accessed at: http://www.mdpi.com/1424-8220/15/3/4810/s1.

\section{Conflicts of Interest}

The authors declare no conflict of interest. 


\section{References}

1. Aydın, M.E.; Kılıçoğlu, T.; Akkılıç, K.; Hoşgören, H. The calculation of electronic parameters of an $\mathrm{Au} / \beta$-carotene/n-Si Schottky barrier diode. Phys. B Condens. Matter 2006, 381, 113-117.

2. Çaldıran, Z.; Deniz, A.R.; Aydoğan, Ş.; Yesildag, A.; Ekinci, D. The barrier height enhancement of the $\mathrm{Au} / \mathrm{n}-\mathrm{Si} / \mathrm{Al}$ Schottky barrier diode by electrochemically formed an organic Anthracene layer on n-Si. Superlattices Microstruct. 2013, 56, 45-54.

3. Aydin, M.E.; Yakuphanoglu, F.; Kılıçoğlu, T. The current-voltage and capacitance-voltage characteristics of molecularly modified $\beta$-carotene/n-type $\mathrm{Si}$ junction structure with fluorescein sodium salt. Synth. Met. 2007, 157, 1080-1084.

4. Al-Ghamdi, A.; Al-Hartomy, O.; Gupta, R.; El-Tantawy, F.; Taskan, E.; Hasar, H.; Yakuphanoglu, F. A DNA Biosensor Based Interface States of a Metal-Insulator-Semiconductor Diode for Biotechnology Applications. Acta Phys. Pol. A 2012, 121, 673-677.

5. Luthra, V.; Singh, R.; Mansingh, A. Effect of protonic acids on the dielectric spectroscopy of polyaniline. Synth. Met. 2001, 119, 291-292.

6. Cerreta, A.; Vobornik, D.; Dietler, G., Fine DNA structure revealed by constant height frequency modulation AFM imaging. Eur. Polym. J. 2013, 49, 1916-1922.

7. Ma, D.-L.; Chan, D.S.-H.; Leung, C.-H. Group 9 Organometallic Compounds for Therapeutic and Bioanalytical Applications. Acc. Chem. Res. 2014, 47, 3614-3631.

8. Steckl, A.J. DNA-A new material for photonics? Nat. Photonics 2007, 1, 3-5.

9. Khatir, N.M.; Banihashemian, S.M.; Periasamy, V.; Ritikos, R.; Majid, W.H.A.; Rahman, S.A. Electrical Characterization of Gold-DNA-Gold Structures in Presence of an External Magnetic Field by Means of I-V Curve Analysis. Sensors 2012, 12, 3578-3586.

10. Okur, S.; Yakuphanoglu, F.; Ozsoz, M.; Kadayifcilar, P.K. Electrical and interface properties of $\mathrm{Au} / \mathrm{DNA} / \mathrm{n}-\mathrm{Si}$ organic-on-inorganic structures. Microelectron. Eng. 2009, 86, 2305-2311.

11. Kim, K.; Yoon, M.; Koo, J.; Roh, Y. Electrical characteristics of oxygen doped DNA molecules. Thin Solid Films 2011, 519, 7057-7059.

12. Gupta, R.K.; Yakuphanoglu, F.; Hasar, H.; Al-Khedhairy, A.A. p-Si/DNA photoconductive diode for optical sensor applications. Synth. Met. 2011, 161, 2011-2016.

13. Ma, D.-L.; He, H.-Z.; Leung, K.-H.; Zhong, H.-J.; Chan, D.S.-H.; Leung, C.-H. Label-free luminescent oligonucleotide-based probes. Chem. Soc. Rev. 2013, 42, 3427-3440.

14. Hibbett, D. Forensic DNA Mini-Prep Using the E.Z.N.A. Kit. Available online: http://www.clarku.edu/faculty/dhibbett/protocols.htm (accessed on 20 October 2013).

15. Imtiaj, A.; Lee, T.; Ohga, S. Sequence Variation of Pleurotus Species Collected From Eastern Asia. Micol. Apl. Int. 2011, 23, 1-5.

16. Cubero, O.F.; Crespo, A.; Fatehi, J.; Bridge, P.D. DNA extraction and PCR amplification method suitable for fresh, herbarium-stored, lichenized, and other fungi. Plant Syst. Evol. 1999, 216, 243-249.

17. Tuğluoğlu, N.; Karadeniz, S. Analysis of current-voltage and capacitance-voltage characteristics of perylene-monoimide/n-Si Schottky contacts. Curr. Appl. Phys. 2012, 12, 1529-1535.

18. Selçuk, A.B.; Bilge Ocak, S.; Aras, F.G.; Oz Orhan, E. Electrical Characteristics of Al/Poly(methyl methacrylate)/p-Si Schottky Device. J. Electron. Mater. 2014, 43, 1-7. 
19. Reddy, V.R.; Reddy, M.S.P.; Lakshmi, B.P.; Kumar, A.A. Electrical characterization of $\mathrm{Au} / \mathrm{n}-\mathrm{GaN}$ metal-semiconductor and $\mathrm{Au} / \mathrm{SiO}_{2} / \mathrm{n}-\mathrm{GaN}$ metal-insulator-semiconductor structures. $J$. Alloys Compound. 2011, 509, 8001-8007.

20. Gupta, R.K.; Yakuphanoglu, F. Photoconductive Schottky diode based on Al/p-Si/SnS2/Ag for optical sensor applications. Sol. Energy 2012, 86, 1539-1545.

21. Cheung, S.; Cheung, N. Extraction of Schottky diode parameters from forward current-voltage characteristics. Appl. Phys. Lett. 1986, 49, 85-87.

22. Bazlov, N.V.; Vyvenko, O.F.; Sokolov, P.A.; Kas'yanenko, N.A.; Petrov, Y.V. Charge-controlled fixation of DNA molecules on silicon surface and electro-physical properties of Au-DNA-Si interface. Appl. Surf. Sci. 2013, 267, 224-228.

23. Farag, A.A.M.; Gunduz, B.; Yakuphanoglu, F.; Farooq, W.A. Controlling of electrical characteristics of Al/p-Si Schottky diode by tris(8-hydroxyquinolinato) aluminum organic film. Synth. Met. 2010, 160, 2559-2563.

24. Karadeniz, S.; Barış, B.; Yüksel, Ö.F.; Tuğluoğlu, N. Analysis of electrical properties of Al/p-Si Schottky contacts with and without rubrene layer. Synth. Met. 2013, 168, 16-22.

25. Çınar, K.; Coşkun, C.; Aydoğan, Ş.; Asıl, H.; Gür, E. The effect of the electron irradiation on the series resistance of $\mathrm{Au} / \mathrm{Ni} / 6 \mathrm{H}-\mathrm{SiC}$ and $\mathrm{Au} / \mathrm{Ni} / 4 \mathrm{H}-\mathrm{SiC}$ Schottky contacts. Nuclear Instrum. Methods Phys. Res. Sect. B Beam Interact. Mater. Atoms 2010, 268, 616-621.

26. Norde, H. A modified forward I-V plot for Schottky diodes with high series resistance. J. Appl. Phys. 2008, 50, 5052-5053.

27. Martin, L.M.; Marples, B.; Lynch, T.H.; Hollywood, D.; Marignol, L. Exposure to low dose ionising radiation: Molecular and clinical consequences. Cancer Lett. 2013, 338, 209-218.

28. Gupta, S.; Muralikiran, M.; Farmer, J.; Cao, L.R.; Downing, R.G. The effect of boron doping and gamma irradiation on the structure and properties of microwave chemical vapor deposited boron-doped diamond films. J. Mater. Res. 2009, 24, 1498-1512.

29. Khalid, D.A.; Hassan, M.A.-T.I.; Faika, A.A. Observation of Hypersensitivity Phenomena in E-Coli Cells after Irradiation by Alpha Particles . J. Rafiden Sci. 2009, 20, 113-120.

30. Mohenned, A.A.S.A.; Hassan, M.A.-T.I. hypersensitivity phenomenon in hydatid protoscolices irradiated by alpha particles. J. Kerbala Univ. 2012, 10, 41-44.

31. Kulkarni, A.; Kim, B.; Dugasani, S.R.; Joshirao, P.; Kim, J.A.; Vyas, C.; Manchanda, V.; Kim, T.; Park, S.H. A novel nanometric DNA thin film as a sensor for alpha radiation. Sci. Rep. 2013, 3, 1-5.

(C) 2015 by the authors; licensee MDPI, Basel, Switzerland. This article is an open access article distributed under the terms and conditions of the Creative Commons Attribution license (http://creativecommons.org/licenses/by/4.0/). 